\title{
Effectiveness of Mindfulness-Based Stress Reduction training on psychological symptoms, pain in patients with thalassemia major
}

\author{
Forough Naghibi' ${ }^{1}$ Hasan Ahadi ${ }^{*}$ (D), Biyuk Tajeri ${ }^{3}$. Mohammad Reza Seairafi ${ }^{3}$
}

\begin{abstract}
1. Department of Psychology, Kish International Branch, Islamic Azad University, Kish Island, Iran
2. Department of Psychology, Faculty of Psychology, Allameh Tabataba'i University, Tehran, Iran

3. Department of Health Psychology, Karaj Branch, Islamic Azad University, Karaj, Iran
\end{abstract}

Recieved: 20 Jan. 2020

Revised: 18 Apr. 2020

Accepted: 28 Apr. 2020

\section{Keywords}

Mindfulness-based stress reduction (MBSR)

Psychological symptoms

Pain

Thalassemia major

Corresponding author

Hasan Ahadi, Department of Psychology, Faculty of Psychology, Tabataba'i University, Tehran, Iran

Email: Drhahadi5@gmail.com

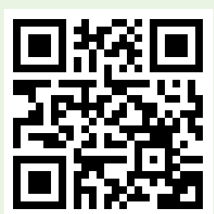

doi.org/10.30699/icss.22.2.45

\section{Abstract}

Introduction: Thalassemia is one of the most common chronic and hereditary diseases. This study's main purpose was to determine the effectiveness of Mindfulness-Based Stress Reduction (MBSR) training on psychological symptoms, pain in patients with thalassemia major.

Methods: This quasi-experimental study with pretest-posttest design with control group was carried out in 2019. Fifty patients with thalassemia major in Bandar Abbas city were selected purposefully and assigned to experimental $(n=25)$ and control $(n=25)$ groups. 8-session training was performed to the experimental group in Mindfulness-Based Stress Reduction. The Beck Anxiety and Depression questionnaire, Brief Pain questionnaire was used for data collection in pretest and posttest phases. Data were analyzed by SPSS 21 software using univariate and multivariate analysis of covariance.

Results: By controlling the pretest effect, there is a significant effect in the Mindfulness-Based Stress Reduction in reducing the anxiety $(\mathrm{F}=32.72)$ and depression $(\mathrm{F}=49.02)$, pain $(\mathrm{F}=25.47),(\mathrm{P}=0.001)$.

Conclusion: The Mindfulness-Based Stress Reduction is an effective method in reducing the psychological symptoms, as well as pain in patients with thalassemia major. 


\title{
اثربخشى آموزش كاهش استرس مبتنى بر ذهن آكاهى بر علائم روانشناختى و درد بيماران مبتلا به تالاسمى مازٔور
}

\author{
فروغ نقيبى'، حسن احدى " (D) ، بيوك تاجرى"، محمدرضا صيرفى"
}

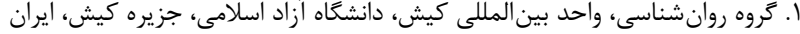

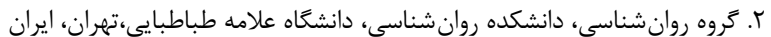

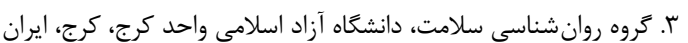

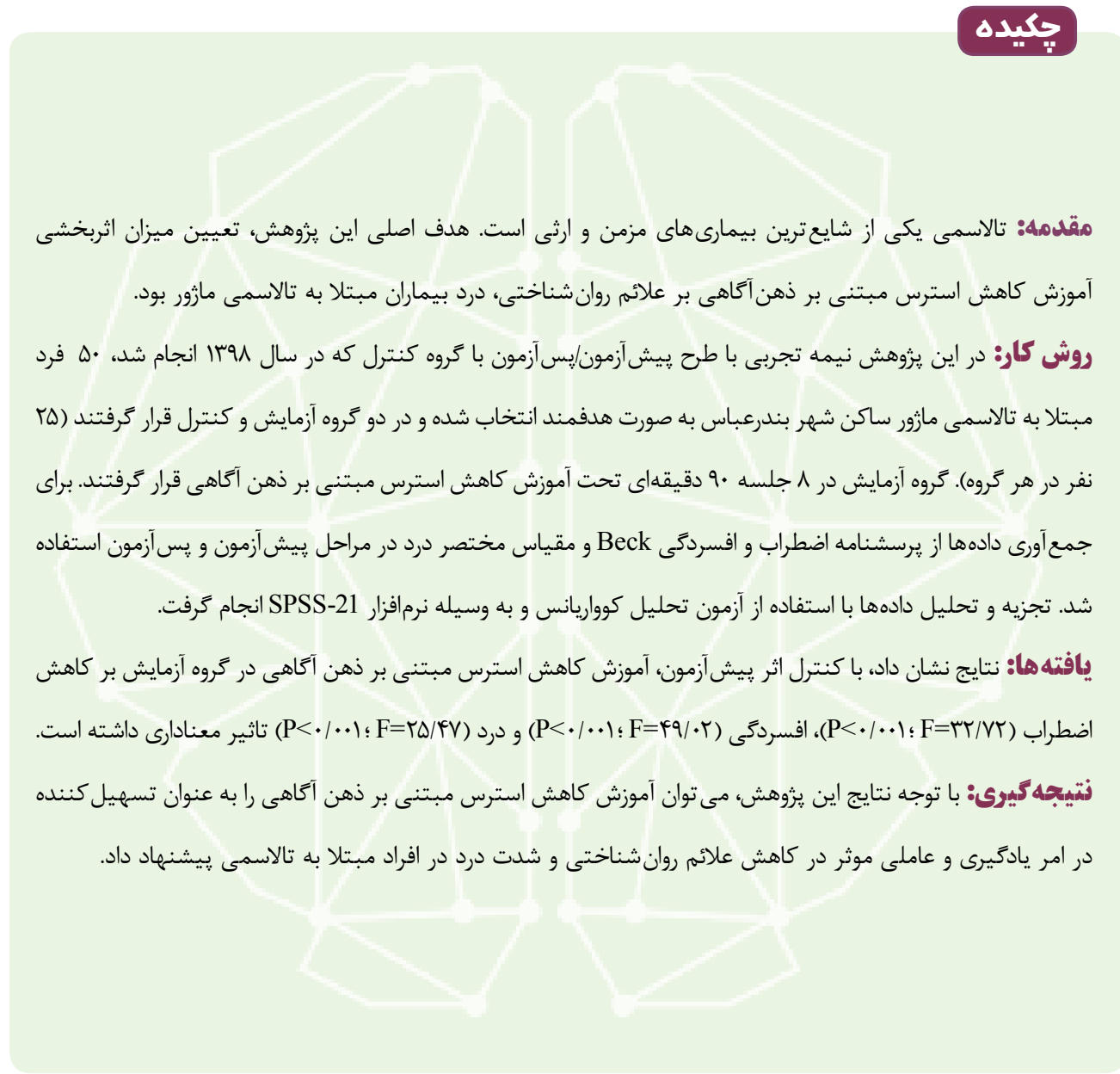

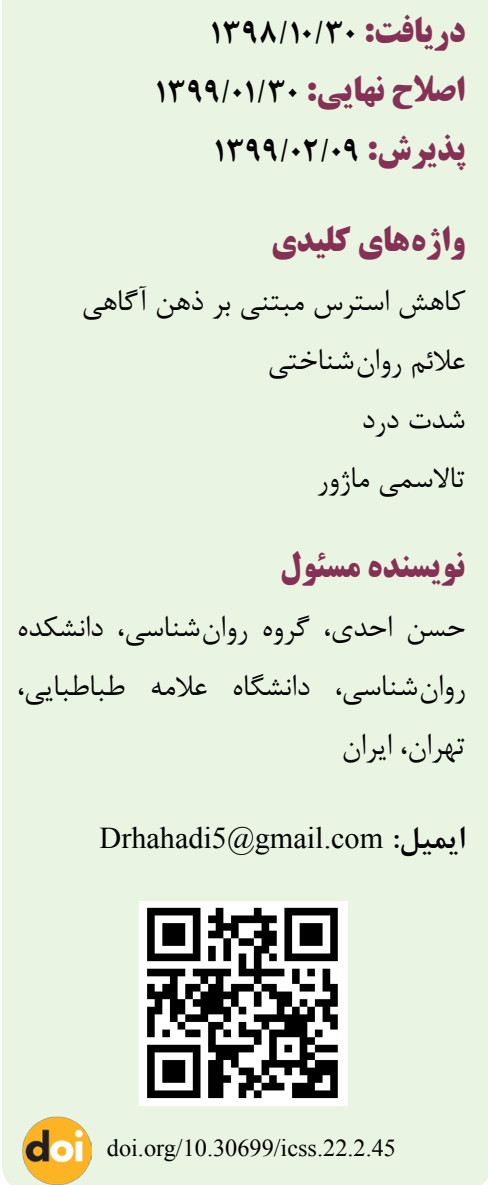

مقلدمه

اين جمعيت افزوده مى شود. تالاسمى تنها يك مشكل بهداشتى براى

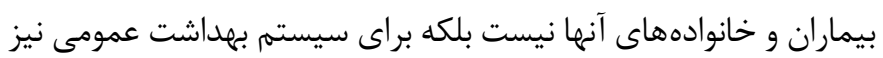
هزينهبر است. اين بيمارى همجنين يكى از بيمارىهاى وراثتى شايع در ايران است (1). مراجعات مكرر اين بيماران به مراكز درمانى جهت ترانسفوزيون خون موجب تغيير شيوه زندكى، غيبتهاى مكرر آنان از
تالاسمى يكى از شايعترين بيمارىهاى مزمن و ارثى است. طبق آمار فدراسيون بين المللى تالاسمى (TIF) Federation Thalassaemia (TIF) (International درمان در دنيا به ثبت رسيده است. حدود · FF ميليون نفر در سراسر

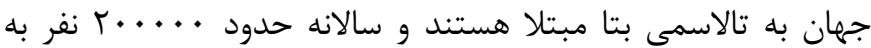


عامدانه شخص نسبت به تجربهاى است كه در حال حاضر در جريان است، اين توجه داراى ويرگَى غيرقضاوتى و همراه با پذيرش است. هدف روش هاى مبتنى بر ذهن آكاهى، كاهش نقش هشيارى محدود شده و برخى از تاثيرات هيجانى و رفتارى يريشان كننده تجارب روانشناختى در بيماران مى باشد (F ( ) مطالعات زيادى به خصوص در سال هاى اخير انجام شده كه به اثرات MBSR در خسترههاى بالينى يرداخته است. به طور كلى در مطالعاتى كه در مورد اثر MBSR بر درد مزمن انجام كرفته است حاكى از كاهش معنادار در علائم جسمانى و روانشناختى در بيماران درد مزمن بعد از شركت در برنامه MBSR بوده است (ه ). در واقع مىتوان كفت مداخلات مبتنى بر ذهن آكاهى صلاحيت خود را در درمان مشكلات روانشناختى مختلف شامل ييشگيرى از عود افسردگى، درد مزمن، سوءمصرف مواد و كاهش ياسخهاى روانشناختى و فيزيكى منفى در برابر استرس نشان دادهاند (1)، MBSR IV). مى تواند با افزايش مهارتهاى مقابلهاى هم بر نشانه هاى افسردگى و هم بر نشانهاى استرس، اضطراب و نكرانى روانشناختى در نوجوانان

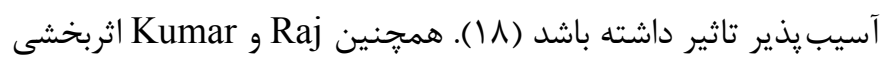
MBSR بر گستره وسيعى از مشكلات روانشناختى (علائم درد، اضطراب، استرس و افسردگى) را نشان دادند (9 (1). بنابراين با توجه به مطالب ذكر شده، يزوهش حاضر با هدف اثربخشى آموزش كاهش استرس مبتنى بر ذهن آكاهى بر علائم روانشناختى و درد بيماران مبتلا به تالاسمى مازور انجام شد.

\section{روش كار}

يزوهش حاضر يك مطالعه مداخلهاى با طرح یيش آزمون/يس آزمون بود

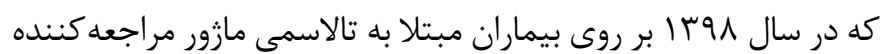
به مراكز تخصصى و بيمارستانهاى سطح شهر بندرعباس انجام شد. انتخاب گروه مداخله بدين صورت بود كه با مساعدت متخصصان آنكولوزى و درمانگاههاى تخصصى سطح شهر بندرعباس 19 بيمار با تشخيص تالاسمى مازور و با توجه به ملاكهاى ورود مطالعه به

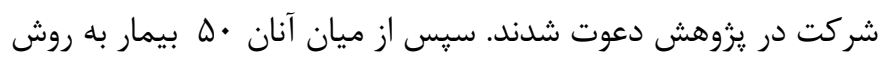
نمونه گيرى هدفمند انتخاب و در دو گروه آزمايش و كنترل قرار گرفتند (ه نفر در هر گروه). ابتدا اطلاعات لازم در زمينه اهداف مطالعه به بيماران ارائه گرديد و آنها با تمايل و اختيار خود وارد مطالعه شدند. معيارهاى ورود به يزوهش شامل: سن بالاى ع إل سال، تشخيص بيمارى تالاسمى مازور توسط متخصص انكولوزى، نداشتن اختلال روانشناختى، عدم دريافت درمان روانشناختى ديگر بود. معيار خروج از مطالعه نيز عدم تمايل افراد به ادامه همكارى و حداكثر دو جلسه غيبت براى هر
مدرسه و كار، كاهش فعاليتهاى اجتماعى، كاهش اعتماد به نفس، احساس بى كفايتى و حقارت ناشى از وابستكى به ديكران، خشم، ناميدى و ترس از مرى زودرس مىشود. علاوه بر اين، تأثيرات نامطلوبى بر

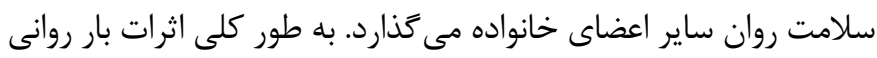

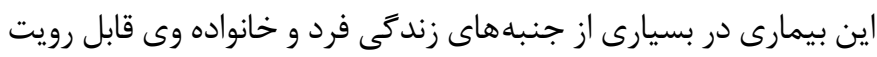

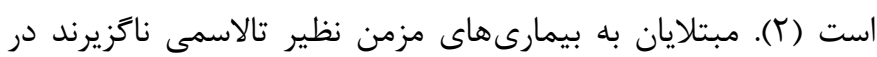
تمام طول زندگى خود تحت درمان مداوم يزشكى قرار باشند و در ادامه به بهي زندگى به اين درمان ها وابسته هستند. نتايج برخى از يزوهشها نش نشان مى دهد •^م درصد مبتلايان به اين بيمارى حداقل دجار يك اختلال روانشناختى مى باشند (זّ). بيشترين ميزان علائم روانشناختى در اين بيماران به ترتيب مربوط به افسردگى، اضطراب، بيمارىهاى روانتنى

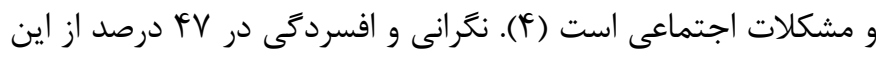
بيماران وجود دارد و اين امر موجب اشكال در امر خودمراقبتى و وضعيت روانى آنها مىشود. افسردگى در اين بيماران مى تواند به علت مزمن بودن بيمارى، درمان طولانى، انتظار مرى زودرس، تغيير وضعيت ظاهرى فرد،

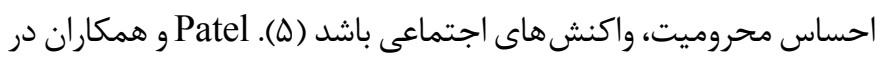
يزوهشى نشان دادند كه بيماران مبتلا به تالاسمى از دورههاى طولانى و متعدد افسردگى و سطح پايين كيفيت زندگى رنج مى برند (4). همجنين Eren و همكاران در يزوهش خود نشان دادند كه معمولاً بيماران مبتلا به تالاسمى دجار نشانه هاى اضطراب و افسردگى مىشوند (V). درد به عنوان نشانهاى شايع هميشه همراه بيماران مبتلا به تالاسمى بوده است. اين بيماران معمولا از سردرد، ضعف، خستخى زودرس، ريزش مو و دردهاى عضلانى اسكلتى شكايت دارند (A). Caytemel و همكاران در يثوهش خود به زخمهاى بسيار دردناى ياى بيماران مبتلا به تالاسمى

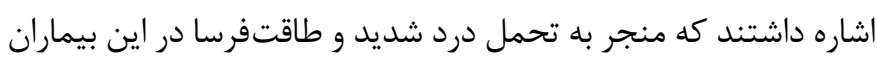
مى گردد (9). Pakbaz و همكاران نيز ميزان درد متوسط در بيماران تالاسمى را الج درصد و درد شديد را در \& | درصد بيماران تزريق خونى كزارش كردند ( • (). با افزايش سن ميزان درد در اين بيماران نيز افزايش مى يابد. تحقيقات همجنين وقوع دردهاى عضلانى و استخوانى و مفصلى را در اندام تحتانى و ستون فقرات در بيماران مبتلا به تالاسمى گزارش كرده اند (^). (1). در ميان درمانهايى كه در دو دهه اخير در مورد درد مزمن و علائم روانشناختى همجون اضطراب و افسردگى مورد توجه قرار گرفته است

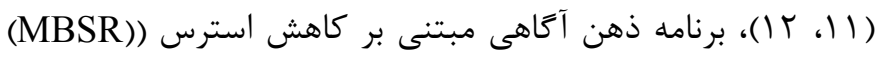
(Mindfulness-Based Stress Reduction دامنهُ وسيعى از افراد مبتلا به اختلالات مرتبط با استرس و درد مزمن طراحى شد (سا (). در اين الگو، ذهن آكاهى يعنى متمركز كردن توجه 


\section{يرسشنامه اضطراب بك (Beck Anxiety Inventory (BAI)} يك مقياس خودسنجى آTوالى است كه اضطراب افراد را مى سنجد. سوالات به صورت، اصلا (•)، خفيف (1)، متوسط (ץ) و شديد (广)

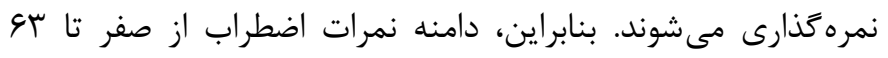

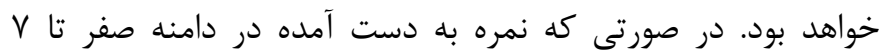

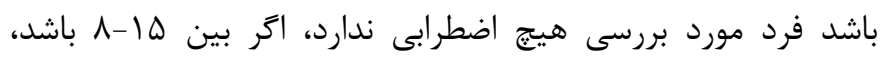

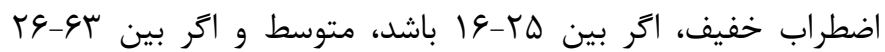
باشد، نشاندهنده اضطراب شديد است (rآ). در ايران مطالعات انجام شده نشان مىدهد كه اين يرسشنامه از يايايى بالايى برخوردار است.

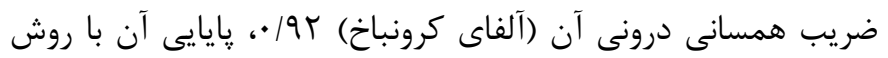

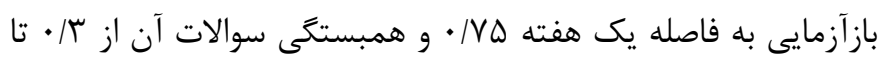

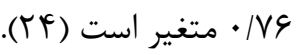

مقياس مختصر درد (Brief Pain Inventory (BPI)

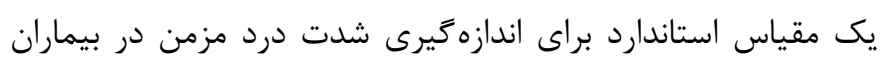

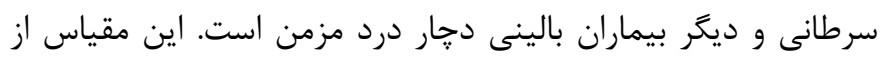

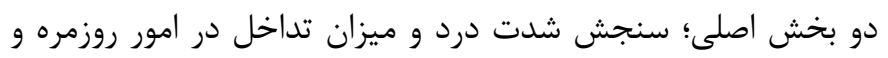

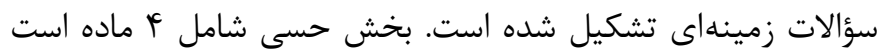

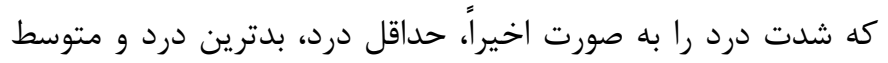

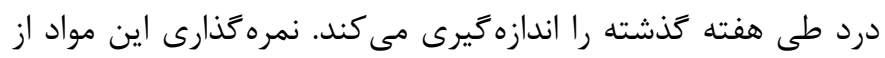

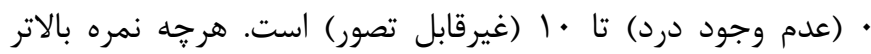
باشد، نشان دهنده شدت بيشتر درد است. بخش ديغر كه ميزان تداخل

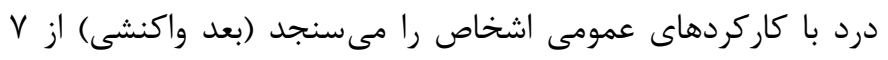

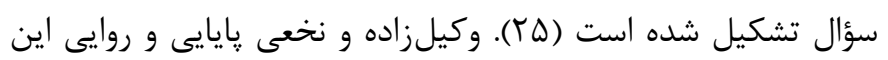

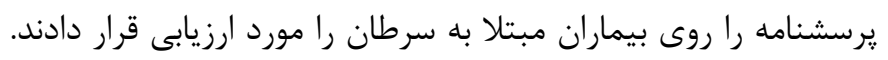

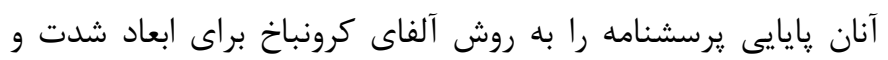

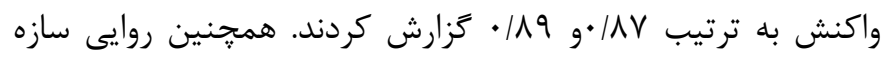

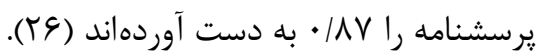

بيمار بود. لازم به ذكر است كه اين يزوهش حاضر داراى كد اخلاق با

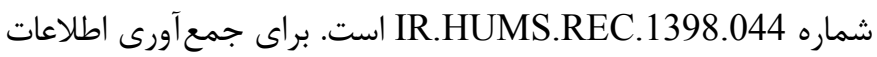

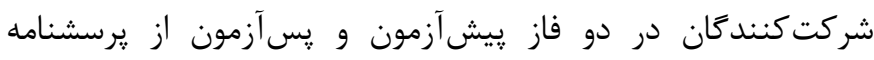

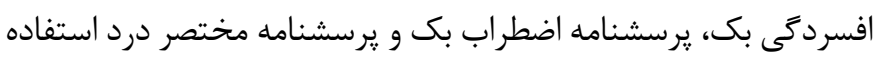

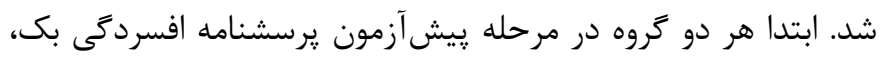

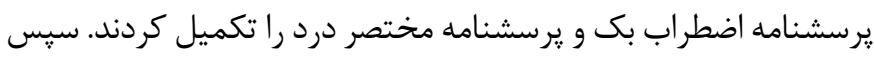

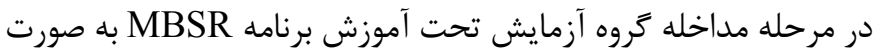
ᄉ جلسه •q دقيقهاى كه بر اساس دستورالعمل Kabat-Zinn (•r) تهيه شده است، قرارگرفتند (جدول (). در نهايت دو هفته يس از درمان

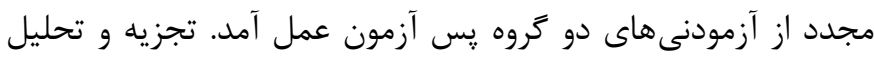

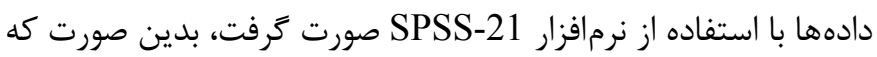

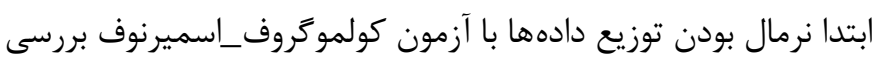
شد. سيس براى بررسى تفاوت دو گروه از نظر متغيرهاى يزوهش آنداز

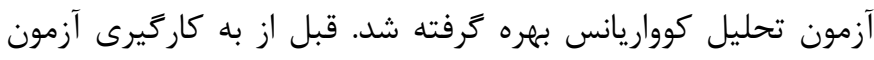
تحليل واريانس، مفروضههاى آن به وسيله آزمون باكس، لامبداى ويلكز و آزمون لون مورد بررسى قرار خرفت.

\section{ير سشنامه افسردَى بك (BDI-II))}

(Beck

اين يرسشنامه كه شامل IT سوال است، به منظور سنجش بازخوردها و

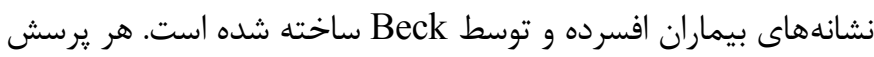

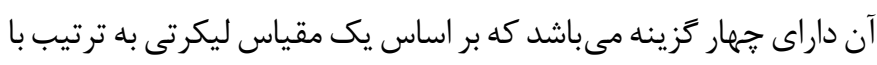

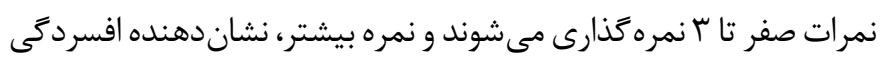

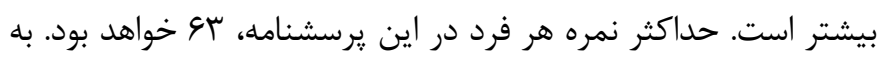

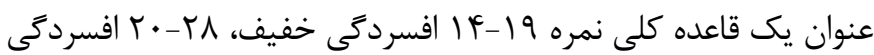

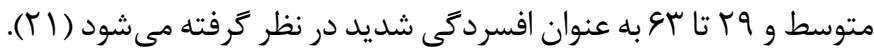
حميدى و همكاران در يزوهشى ثبات داخلى اين يرسشنامه را با روش

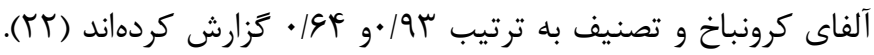

$$
\text { جدول ا. شرح جلسات آموزش كاهش استرس مبتنى بر ذهن آكاهى }
$$

تعيين اهداف جلسه، تمرين خوردن كشمش، دادن يسخوراند و بحث در مورد تمرين خوردن، تمرين وارسى بدنى، آغاز تمرين با تمركز بر

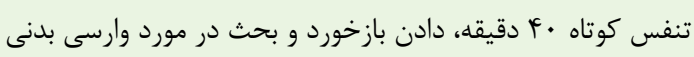

تمرين وارسى بدنى، بازنكرى تمرين، بازنكرى تكليف خانكى، تمرين افكار و احساسات (ييادهروى در خيابان)، ثبت وقايع خوشايند، مراقبه نشسته • ا تا ها دقيقه، توزيع جزوات جلسه دوم بين شركت كنندگان، ارايه تكاليف خانكى، نوار وارسى بدنى ع بار در ل روز، تنفس با حضور 


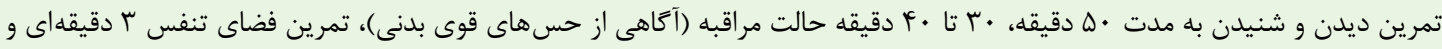
بازنكرى آن، قدم زدن با حضور ذهن و بازنكرى آن، تهيه فهرستى از وقايع ناخوشايند

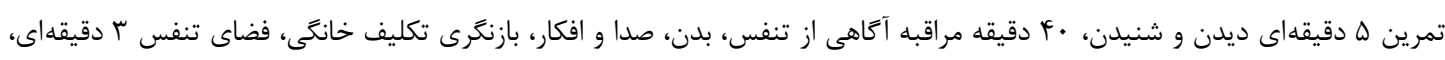
بررسى تكاليف تجربيات ناخوشايند، فضاى تنفس ب دقيقهاى

جلسه جهارم

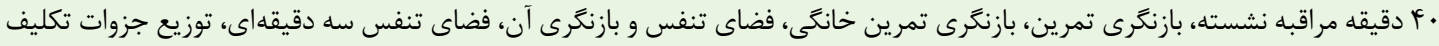
خانكَى، فضاى تنفس سه دقيقهاى به طور منظم (r بار در روز) جلسه ينجم

مراقبه نشسته · r دقيقهاى، بازنَرى تمرين، بازنكرى تكليف خانكَى (شامل مراقبه بدون نوار وتنفس عميق)، آماده شدن براى اتمام دوره، خلق، افكار وتمرين نقطه نظرات يا افكار جانشين، زمان تنفس وبازنكرى آن، توزيع جزوات جلسه 9 وتعيين تكليف خانكى • P اقيقه مراقبه نشسته، بازنكرى تكاليف خانكى، تهيه فهرستى از فعاليتهاى لذتبخش و فعاليتهايى كه منجر به حس از عهده بر آمدن مى شود، برنامه ريزى و تهيه يك برنامه مناسب براى جنين فعاليتهايى، فضاى تنفس r دقيقهاى به عنوان كام اول براى داشتن حضور ذهن، توزيع جذوات جلسه ششم بين توزيع كنندًان، دادن تكالف خانكى

تمرين وارسى بدنى، بازنكرى تكليف خانگى (شامل نظامهاى هشداردهنده اوليه و برنامههاى عمل)، بازنگرى كل برنامه، بحث در مورد اين

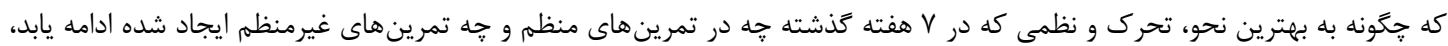
وارسى و بحث در مورد برنامهاو يافتن دلايل مثبت براى ادامه تمرين، توزيع جزوات جلسه ^ بين شركت كنندگان، پايان دادن به كلاسها

جلسه هشته با آخرين مراقبه
جلسه ششم

جلسه هفتم

يافته ها

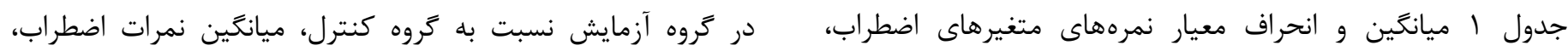

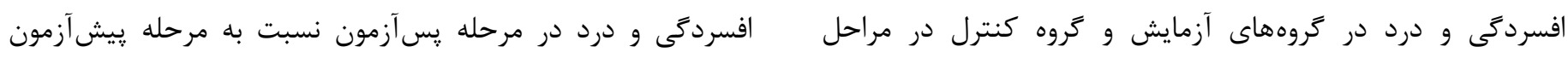

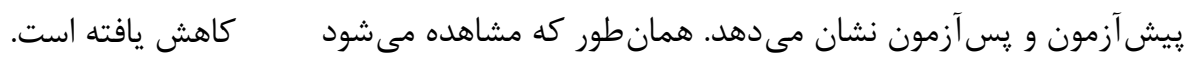

جدول ا. ميانكين و انحراف معيار نمرههاى متغيرهاى اضطراب، افسردىى و درد در تروههاى مورد مطالعه

\begin{tabular}{|c|c|c|c|c|}
\hline \multicolumn{2}{|c|}{ گروه كنترل } & \multicolumn{2}{|c|}{ گروه آزمايش } & \multirow{2}{*}{ متغير ها } \\
\hline يس آزمون & ييش آزمون & يس آزمون & ييش آزمون & \\
\hline $19 / \curlyvee \pm 9 / \uparrow$ & $19 / \wedge \pm 1 \cdot 10$ & $\mid \varepsilon / \mu \pm 1 \cdot / 4$ & $\mid \Lambda / r \pm I r / V$ & اضطراب \\
\hline$|9 / r \pm| r / \mid$ & $19 / 1 \pm 1 \% / F$ & $\mid r / r \pm V / \mathbb{F}$ & $|\varepsilon / r \pm 1| / \Lambda$ & افسردگى \\
\hline$\Lambda / \Delta \pm I / \Gamma$ & $\Lambda / T \pm 1 / \Delta$ & $V / I \pm I / r$ & $\wedge \pm 1 / 9$ & شدت درد \\
\hline
\end{tabular}

يروهش معنادار نبود (ه>/P>•)، بنابراين مىتوان نتيجه كرفت كه متغيرهاى يزوهش داراى توزيع نرمال مىباشند. نتايج آزمون لون نيز

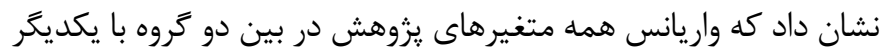

براى بررسى ييش فرض هاى نرمال بودن توزيع دادها و همكنى واريانس متغيرها به ترتيب از آزمون كلموكروف_اسميرنوف و آزمون لون استفاده كرديد. نتايج آزمون كلموكروف_اسميرنوف براى هيج يك از متغيرهاى 
از كنترل ييشآزمون بين دو تروه آزمايش و كنترل در متغيرهاى

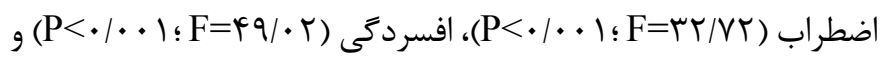

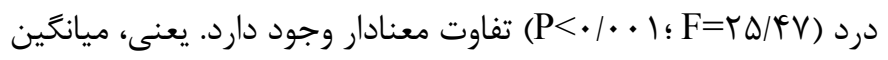

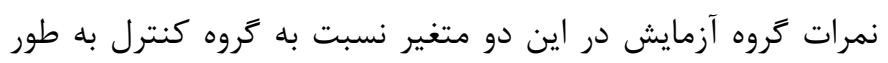
معنادارى كاهش يافته است.
تفاوت معنادارى ندارند (ه> P> P)، بنابر اين فرض همحَنى واريانسها نيز

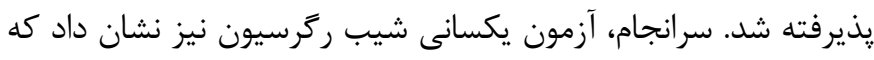

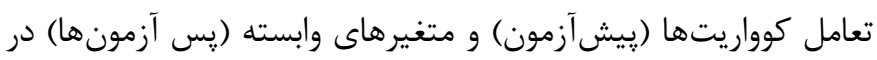

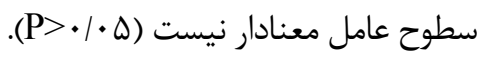

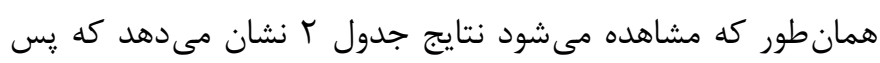

جدول r. تحليل كواريانس يك راهه براى نمرات ييش آزمون يس آزمون متغيرهاى يُوهش در كروه آزمايش و كروه كنترل

\begin{tabular}{|c|c|c|c|c|c|c|}
\hline $\mathbf{P}$ & اندازه اثر & $\mathbf{F}$ & مجذذوراتين & Df & مجذورات & متغير \\
\hline $\mathrm{P}<\cdot / \cdot .1$ &. $\mid 94$ & Tr/VT & $\Lambda \cdot F / F \Delta$ & 1 & $\Lambda \cdot F / F \Delta$ & اضطراب \\
\hline $\mathrm{P}<\cdot \mid \cdot .1$ & . IVF & $r q / \cdot r$ & IITE/FT & 1 & llTg/4T & افسردگى \\
\hline $\mathrm{P}<\cdot \mid \cdot .1$ & . $/ \Delta T$ & $r \Delta / F V$ & VTA/VV & 1 & VTN/VV & درد \\
\hline
\end{tabular}

مخالفتورزى با افكارخودآيند منفى و در نتيجه مشكل كشايى برنامهريزى شده گردد و از اين طريق هم به كاهش ادراك درد و هم به افزايش مهارتهاى كارآمد منتهى گردد. از طرفى ديخر آموزش خودكنترلى به افزايش مهارگرى و خويشتن دارى بيماران در مقابله با درد مى انجامد. در اين آموزش ها فرد هيجانات منفى خود را كنترل كرده و مسئوليت مشكلات خود را به عهده مى گيرد و با تعديل يا تصحيح آنها و ارزيابى مجدد مثبت روى مشكلات خود به مهارگرى و

همجنين ارتقاى وضعيت مقابلهاى خود كمك مى كند (ج) (؟). از دلايل ديخر تبيين يافتههاى اين مطالعه اين است كه آموزش ذهن آكاهى با كمك به افراد در شناخت بهتر خود و افزايش تجربه نكرشى غيرقضاوتى، يذيرا بودن و... سبب مىشود كه افراد در ارتباط با ديكران از

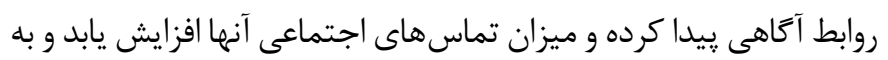
نحوى بر رفتارهاى بينفردى نيز اثربخش باشد. به عبارتى مىتوان كفت

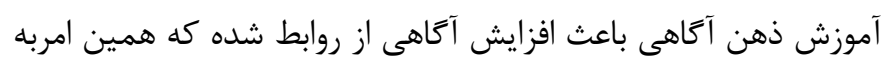
نوبه خود استرس را كاهش مى دهد. از سوى ديخر، در اين مداخله به بيان منابع معمول به وجود آورنده استرس در اين بيماران و واكنش مناسب به استرس يرداخته شد كه خود سبب برخورد آكاهانهتر با موقعيتهاى استرسزاى معمول و در بعضى موارد حذف اين منابع مى شود. همجنين

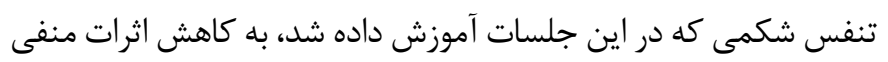
استرس منجر مى شود. تهيه ليست افكار و خواستههاى غيرمنطقى نيز به شناخت آكاهانهتر افكار ايجادكننده اضطراب و استرس كمك مى كند.

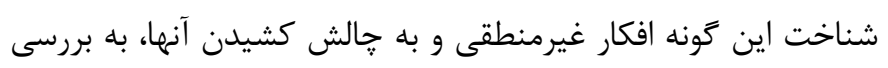

يزوهش حاضر با هدف بررسى اثربخشى آموزش كاهش استرس مبتنى ذآى

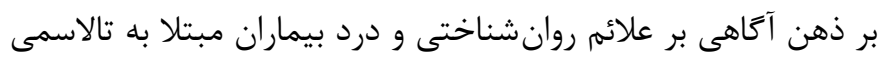

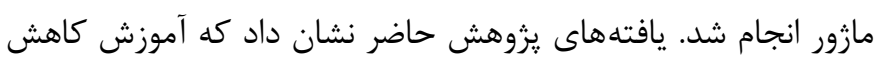
استرس مبتنى بر ذهن آكاهى باعث تغيير علائم روانشناختى و شدت درد گروه آزمايش نسبت به گروه كنترل شده است. به عبارت ديخر، بهني ميزان علائم روانشناختى و شدت درد در افرادى كه در جلسات آموزش كاهش استرس مبتنى بر ذهن آكاهى شركت كرده بودند در مقايسه با گروه كنترل كاهش معنادارى داشته است. اين يافته با نتايج مطالعات ديخر همسو است (19-ه 1). در تبيين يافتههاى اين مطالعه مى توان كفت كيفيت درد به واسطه شدت، تازگى، رِيشبينى

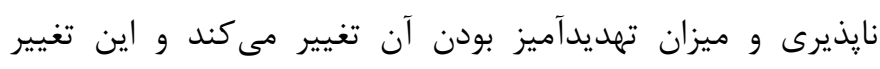
مىتواند باعث تمركز فرد بر روى درد شده و به نوسان افزايش درد

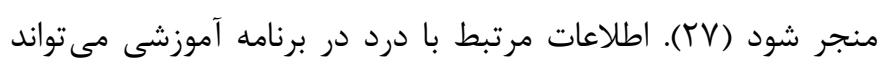
به كاهش درد منجر شده و باعث شود كه بيماران نخرانى كمترى از

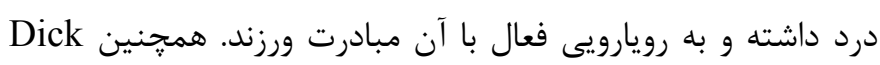
و Rashiq معتقدند آموزش كاهش استرس مبتنى بر ذهن آتاهى از طريق آموزش راهبردهاى مقابلهاى فعال باعث افزايش توان افراد براى مقابله با درد شده و افراد ناتوانايى كمترى را گزارش مى كند. به نظر

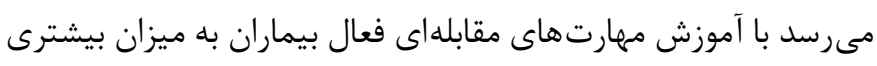
به ارزيابى مجدد يديده درد يرداخته و از طريق آموزش مهارتهاى

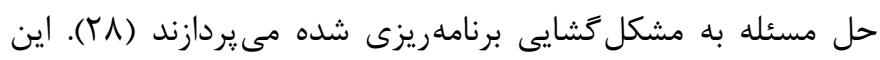

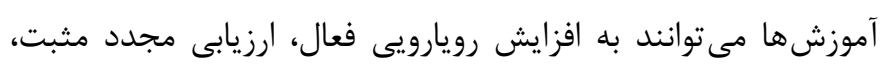


همجون ساير يزوهشها با محدوديت هايى مواجه بود. از جمله اين كه در يزوهش حاضر از ابزارهاى خودَزارشدهى استفاده شد كه ممكن است افراد در ابراز مشكلات خود و ياسخ به يرسشنامهها صداقت و دقت كامل را به خرج نداده باشند و با توجه به تاثير عوامل انسانى، در نتايج يزوهش محدوديتهايى در اين خصوص به وجود آمده باشد. همجنين بايد در نظر داشت كه يزوهش حاضر در شهر بندرعباس اجرا شده و تعميم نتايج به ديخر نقاط كشور بايد با احتياط صورت گيرد، به همين دليل در تفسير نتايج يزوهش، بايد اين محدوديتها مد نظر قرار گيرد.

\section{زتنيجه كيرى}

با توجه نتايج اين يزوهش، مى توان آموزش كاهش استرس مبتنى بر ذهن آكاهى را به عنوان تسهيل كننده در امر يادگيرى و عاملى موثر در كاهش علائم روانشناختى و شدت درد در افراد مبتلا به تالاسمى مازور ييشنهاد داد. همجننين ريشنهاد مىشود با توجه به تاثير اين آموزش در كاهش علائم روانشناختى و شدت درد از نتايج يزوهش هاى انجام شده در اين زمينه به صورت عملى در مراكز مشاوره و مراكز درمانى

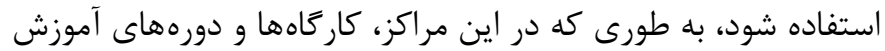
كاهش استرس مبتنى بر ذهن آحاهى براى بيماران و درمانگران در نظر كرفته شود.

\section{تشكر و قلدرفاذى}

بر خود لازم مى دانيم از تمامى افرادى كه ما را در انجام اين يزوهش يارى كردند، كمال تشكر و قدردانى را داشته باشيم.

\section{References}

1. Sadeghloo A, Shamsaee P, Hesari E, Akhondzadeh G, Hojjati H. The effect of positive thinking training on the quality of life of parents of adolescent with thalassemia. International Journal of Adolescent Medicine and Health. 2019;1. (ahead-of-print)

2. Rezaee N, Navidian A, Abbasi F. The impact of a group supportive training on caregiving burden in the mothers of children with thalassemia major. Journal of Hayat. 2017;23(2):126-137. (Persian)

3. Ramazani T, Safarizadeh MH, Alimirzaei R, Rahbarifar S, Fatemi MS. Relationship between quality of life and psychologi-
منطقىتر و واقعبينانهتر اين افكار منتتهى مىشود كه خود باعث كاهش اضطراب مىشود. با توجه به تمركز آموزش ذهن آكاهى بر فرآيندهاى درون شخصى، اين آموزش به افراد كمك مى كند تا روابطشان را با حالتهاى درونى، تفكرات و احساساتشان تغيير دهند و بدين صورت إن سبب كاهش نشانهاى درونى اضطراب مىشود. همجنين، آموزش روشهاى آرميدگى عضلانى، تمركز عميق، آرميدگى ماهيجٍاى همراه با آرامسازى فكرى باعث عادى شدن جريان تنفس و كاهش نشانههاى بيرونى اضطراب مىشود ( • (l). علاوه بر اين، آموزش ذهن آثاهى از طريق ايجاد شناخت آكاهانه از وضعيت خود، همراه با شناخت مسايل تسهيل كننده افسردگى مى تواند به برخورد آكاهانه تر با اين مسايل منجر شود. همجنين تهيه ليست افكار منفى روزانه و جايكزينى اين جمله ها و افكار با افكار مثبت تا حدودى به تغيير رويه افكار منفى و كاهش اثر مخربشان كمك خواهد كرد. آموزش ذهن آكاهى سبب مى شود كه عناصر نخرش ها، توجه و قصد همزمان در فرد تقويت شود و تقويت اين مولفهها به وى اجازه مى دهد ديدكاهى را در تجربيات رشد دهد كه از حالت قضاوتى، عينى و غير مشروح افكار، احساسات و هيجانات به عنوان گ يديدهاى كذرا بيرون آيد به سمت تفكراتى غير قضاوتى و يذيرا يیش رود و انعطاف يذيرى را در فر آيندهاى ذهنى خود حس كند. به عبارت ديگر، اين تغيير باعث مىشود كه شخص بتواند الكوهاى عادتى يا حالتهاى ذهنى را شناسايى و قطع نموده و ياسخهايى را آغاز كند كه بيشتر منعكس كننده باشد تا واكنشى لـى كه همين امر به آتاهى كامل از فرآيندهاى ذهنى ناكارآمد و جايخزين ساختن فرآيندهاى ذهنى سالم منجر مىشود ( آ). اين يزوهش نيز

cal disorders of patients with thalassemia. The Scientific Journal of Iran Blood Transfusion Organization. 2015;11(4):362-372. (Persian)

4. Bala J, Sarin J. Empowering parents of children with thalassemia. International Journal of Nursing Care. 2014;2(1):2225. (Persian)

5. Hooshmandi R, Akabarian S, Bahreini M, Mirzaei K. The relationship between social support and depression in patients with thalassemia major in Bushehr, Iran. Nursing journal of the Vulnerable. 2015;2(4):1-14. 
6. Patel P, Beamish P, Da Silva TL, Kaushalya D, Premawardhena A, Williams S, et al. Examining depression and quality of life in patients with thalassemia in Sri Lanka. International Journal of Noncommunicable Diseases. 2019;4(1):27-33.

7. Eren R, Karısmaz A, Aslan C, Dogu MH, Altındal S, Yokus O, et al. Beta thalassemia minor patients: Not tired, but depressed and anxious. HemaSphere. 2019;3(1):1066-1067

8. Ghazanfari S. Evaluation of musculoskeletal complaints of 15-50 year old thalassemic patients referred to hematology-oncology clinics of Shiraz University of Medical Sciences $[\mathrm{PhD}$ Dissertation]. Yazd: Azad Islamic University of Yazd;2015.

9. Caytemel C, Topaloglu Demir F, Buyukbabani N, Turkoglu Z, Uzuner EG. Multifactorial painful leg ulcers due to hyperhomocysteinemia, plasminogen activator inhibitor-1 4G/5G heterozygote gene mutation, and beta thalassemia minor: A case report. The International Journal of Lower Extremity Wounds. 2019;18(3):339-341.

10. Pakbaz Z, Treadwell M, Yamashita R, Quirolo K, Foote D, Quill L, et al. Quality of life in patients with thalassemia intermedia compared to thalassemia major. Annals of the New York Academy of Sciences. 2005;1054(1):457-461.

11. Azami E, Hajsadeghi Z, Yazdi-Ravandi S. The comparative study of effectiveness of training communication and emotional skills on parenting stress of mothers with autism children. Zanko Journal of Medical Sciences. 2017;18(56):1-11. (Persian)

12. Hajsadeghi Z, Yazdi-Ravandi S, Pirnia B. Compassion-focused therapy on levels of anxiety and depression among women with breast cancer: A randomized pilot trial. International Journal of Cancer Management. 2018;11(11):e67019.

13. Rosenzweig S, Greeson JM, Reibel DK, Green JS, Jasser SA, Beasley D. Mindfulness-based stress reduction for chronic pain conditions: Variation in treatment outcomes and role of home meditation practice. Journal of Psychosomatic Research. 2010;68(1):29-36.

14. Masumian S, Shair MR, Shams J, Momenzadeh S. The effect of mindfulness-based stress reduction therapy on self-efficacy of the female with chronic low back pain. Research in Medicine.
2013;37(3):158-163.

15. Nasimi Far N, Heidari A, Davoudi I. Mindfulness-Based Stress Reduction: An effective treatment for improving painful pain and reduce disturbance in daily performance. 4th International Congress on Psychosomatic. 2012 Oct 17-19; Khorasgan, Iran;2012. (Persian)

16. Azimian S. The effectiveness of mindfulness-based cognitive therapy on depression and anxiety in hemodialysis patients [MSc thesis]. Tehran:University of Rehabilitation Sciences and Social Welfare;2016. (Persian)

17. Abdolghaderi M. Comparison of the effectiveness of mindfulness and cognitive behavioral therapy training in pain, anxiety and depression in patients with chronic low back pain [MSc thesis]. Guilan:Guilan University;2013. (Persian)

18. Duncan LG, Coatsworth JD, Greenberg MT. A model of mindful parenting: Implications for parent-child relationships and prevention research. Clinical Child and Family Psychology Review. 2009;12(3):255-270.

19. Raj A, Kumar P. Efficacy of mindfulness based stress reduction (MBSR): A brief overview. Journal of Disability Management and Rehabilitation. 2019;4(1):73-81.

20. Kabat-Zinn J. Full catastrophe living. New York:Delta Publishing; 1990.

21. Beck AT, Steer RA, Brown GK. Beck depression inventory-II. San Antonio. 1996;78(2):490-498

22. Hamidi R, Fekrizadeh Z, Azadbakht A, Garmaroudi GH, Taheri Tanjani P, Fathizadeh SH, et al. Validity and reliability Beck Depression Inventory-II among the Iranian elderly Population. Journal of Sabzevar University of Medical Sciences. 2015;22(1):189-198. (Persian)

23. Beck AT, Steer RA. Manual for the Beck Anxiety Inventory. San Anto:Psychological Corporation;1990.

24. Kaviani H, Mousavi AS. Psychometric properties of the Persian version of Beck Anxiety Inventory (BAI). Tehran University Medical Journal. 2008;65(2):136-140. (Persian)

25. Kroenke K, Theobald D, Wu J, Tu W, Krebs EE. Comparative responsiveness of pain measures in cancer patients. The 
Journal of Pain. 2012;13(8):764-772.

26. Vakilzadeh P, Nakhaee N. The reliability and validity of the Persian version of the brief pain inventory in cancer patients. Journal of Rafsanjan University of Medical Sciences. 2006;5(4):253-258. (Persian)

27. Eccleston C, Crombez G. Pain demands attention: A cognitive-affective model of the interruptive function of pain. Psychological Bulletin. 1999;125(3):356-366.

28. Dick BD, Rashiq S. Chronic low back pain: Review of treatment practices and standards. Journal of Behavior Analysis in Health, Sports, Fitness and Medicine. 2008;1(1):19-25.
29. Golchin N, Janbozorgi M, Alipour A, Agah Heris M. The effi cacy of cognitive behavioral therapy on using coping strategies and decreasing pain among females with chronic back pain. Journal of Fundamentals of Mental Health. 2011;13(2):160-169. (Persian) 30. Tanay G, Lotan G, Bernstein A. Salutary proximal processes and distal mood and anxiety vulnerability outcomes of mindfulness training: A pilot preventive intervention. Behavior Therapy. 2012;43(3):492-505.

31. Dehestani M. The effectiveness of mindfulness-based stress reduction program on depression, anxiety and depression of female students. Journal of Thought \& Behavior in Clinical 